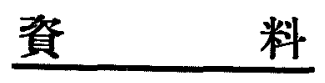

\title{
INDUCING SOMATIC MUTATION BY APPLYING X-RAYS TO GERMINATING SEEDS OF ORYZA SATIVA
}

\author{
Yoshitaka ImaI and Kichiji Kasahara \\ Furitsu-Kôtôgakko, Tokyo
}

Various chlorophyll deficiencies due to gene mutation were induced in Oryza sativa at a high frequency by means of $\mathrm{x}$-rays that were irradiated at gametogenesis or at fertilization. ${ }^{1)}$ A further test was made by subjecting the germinating seeds of this plant to same rays, according to the method of STADLER. ${ }^{2)}$

Germinating seeds of a pure line of an agronomical variety, Sen-ichi (撰 -), were $x$-rayed by a current of $5 \mathrm{ma}$. from a Coolidge tube with a molybdenum anticathode at $50 \mathrm{kv}$. for 90 minutes at a distance of $25 \mathrm{~cm}$. The ears of 868 plants thus treated at their germination were examined for their progenies in the seedling bed. Out of 9272 ear pedigrees, 220 gave offspring containing some chlorophyll deficient seedlings, the details being as shown in Table $\mathrm{I}$, whereas others bred true to normal green.

Table 1. Number of ear pedigrees that segregated mutant seedlings.

\begin{tabular}{c|c|c|c|c|c|c}
\hline Class & Chlorina & Xanthic & $\begin{array}{c}\text { Cream } \\
\text { white }\end{array}$ & Variegated & Miscellaneous & Total \\
\hline A & 35 & 12 & 104 & 11 & 3 & 165 \\
B & 2 & 2 & 21 & 28 & 2 & 55 \\
\hline Total & 37 & 14 & 125 & 39 & 5 & 220 \\
$\%$ & 16.82 & 6.36 & 56.82 & 17.73 & 2.27 & 100 \\
\hline
\end{tabular}

Under class A we collected those ear pedigrees that segregated recessive chlorophyll deficient seedlings at a $3:$ I ratio or en masse, and in class B those containg one or two mutants of sporadic occurrence. The proportion of the affected ear pedigrees to the total is 2.37 per cent, that is, 1.78 per cent of class $A$ and 0.59 per cent of class B. Under the natural, or untreated condition, chlorophyll deficient mutation is rather rare, though plastid muta-

I) ІмАI, Y., r935, Chlorophyll deficiencies in Oryza sativa induced by x-rays. Jap. Jour. Genetics $11:$ 157-161.

2) Stadler, L. J., 1928, Mutations in barley induced by x-rays and radium. Science $68: 186$ 187. I930, Somatic effects of x-rays in plants. Jour. Heredity $21: 3^{-19}$. 
tion of sporadic occurrence has been observed at times. In the treated case too, the majority of variegated seedlings in class $B$ seem to be conditioned by such plastid mutation. However, general mutants, at any rate most of them, including various chlorophyll deficiencies, are regarded as due to gene mutation induced by $\mathrm{x}$-rays at somatogenesis. There was no case in which all the ear pedigrees of an individual segregated mutants, somatic mutation affecting the progeny of only a part of the entire plant. The number of affected ears per individual is found in Table 2.

Table 2. The frequency distribution of the number of affected ears per individual.

\begin{tabular}{c|c|c|c|c|c|c|c|c|c|c}
\hline Affected ears & 0 & 1 & 2 & 3 & 4 & 5 & 6 & 7 & 8 & Total \\
\hline Frequency & 750 & 69 & 24 & 9 & 10 & 2 & 3 & 0 & 1 & 868 \\
\hline
\end{tabular}

The affected individuals attained to 118 , or 13.59 per cent. In most cases, only a single ear was affected by somatic mutation, the frequency diminishing with increase of affected ears per individual.

發芽しつ」ある稻の種子に放射したX一線によって 誘發せる體細胞突然變異

今井喜孝笠原基知 治

府立高等學校 (東京)

摘 要

水稻㩲一」の發芽を開始した種子に X 線を放射した處，とれから抽出した穗數 9272 中 220 穗からは次世代に種々の葉線素不完全苗を生じた。その大部分は體細胞に惹起した遺傳子然然 變異によるものである。 